\title{
Formation of $\mathrm{BH}_{3}$ Adducts with Pyridine-2-Methylaminophosphine ligands: An experimental and computational study
}

\author{
HARINATH ADIMULAM, DWIJENDRA P KUKRI, BHABANI S MALLIK* and \\ TARUN K PANDA* \\ Department of Chemistry, Indian Institute of Technology Hyderabad, Kandi 502285 , \\ Sangareddy, Telangana, India \\ e-mail: bhabani@iith.ac.in; tpanda@iith.ac.in
}

MS received 18 August 2015; revised 26 October 2015; accepted 17 November 2015

\begin{abstract}
The reaction of pyridine-2-methylaminophosphine $\left[\mathrm{C}_{5} \mathrm{H}_{4} \mathrm{~N}-\mathrm{CH}_{2} \mathrm{NHPPh}\right.$ (1) and pyridine-2methylphosphinoselenoic amide $\left[\mathrm{C}_{5} \mathrm{H}_{4} \mathrm{~N}-\mathrm{CH}_{2} \mathrm{NHP}(\mathrm{Se}) \mathrm{Ph}_{2}\right]$ (2) with $\mathrm{BH}_{3} \cdot \mathrm{SMe}_{2}$ yields the corresponding adducts $\left[\mathrm{C}_{5} \mathrm{H}_{4} \mathrm{~N}\left(\mathrm{BH}_{3}\right)-\mathrm{CH}_{2} \mathrm{NHP}\left(\mathrm{BH}_{3}\right) \mathrm{Ph}_{2}\right](\mathbf{1 a})$, and $\left[\mathrm{C}_{5} \mathrm{H}_{4} \mathrm{~N}\left(\mathrm{BH}_{3}\right)-\mathrm{CH}_{2} \mathrm{NHP}(\mathrm{Se}) \mathrm{Ph}_{2}\right](\mathbf{2 a})$, respectively. The solid state structures of both the compounds were established by single crystal X-ray diffraction analysis. The phosphorus and the pyridine nitrogen atoms are coordinated to the boron atom in the case of $\mathbf{1 a}$ whereas only pyridine nitrogen atom is attached to the $\mathrm{BH}_{3}$ group in the case of $\mathbf{2 a}$. To understand the nature of $\mathrm{P}-\mathrm{B} / \mathrm{N}-\mathrm{B}$ bonds and to compare the basicities of pyridine nitrogen, amino nitrogen and phosphorus atoms, density functional theoretical (DFT) calculations were performed on the $\mathrm{BH}_{3}$ adducts $\mathbf{1 a}$ and $\mathbf{2 a}$. The results are consistent with the experimental results.
\end{abstract}

Keywords. Pyridine; Borane; DFT calculation; X-ray analysis; HOMO; LUMO.

\section{Introduction}

Various P-N ligands are often used in organometallic chemistry to achieve well-defined reaction centers. ${ }^{1,2}$ The basicity of the nitrogen atom adjacent to phosphorus in aminophosphines has been the subject of much discussion. ${ }^{3}$ Today it is well-accepted that in acyclic phosphinamines the tricoordinate nitrogen atom assumes a planar configuration with respect to its substituents and thus demonstrates diminished basicity due to enhanced $\mathrm{N}(\mathrm{p} \pi)-\mathrm{P}(\mathrm{d} \pi)$ bonding. ${ }^{3,4}$ Due to lack of crystallinity, solid-state structural information on phosphinamine compounds in which phosphorus atom is trivalent is currently less compared to that for fourcoordinate phosphorus compounds, which is inadequate for comparison. Previous studies have described that acyclic phosphinamines behave as "P-donors only" in their reactions with Lewis acid diborane. ${ }^{5}$ On the other hand, bis-(borane) adducts are well-known to form with phosphinamines of the type $\mathrm{P}\left(\mathrm{OCR}_{2} \mathrm{CH}_{2}\right)_{2} \mathrm{~N}(\mathrm{R}=\mathrm{H}$, $\mathrm{Me})$. Here, the nitrogen atom in the constrained bicyclic structure possesses a pyramidal geometry, which presumably weakens the $\mathrm{p} \pi-\mathrm{d} \pi$ interaction and enables nitrogen to exhibit an enhanced basic character. ${ }^{6}$ Krannich et al., reported by NMR studies, that even P-B bonded mono-adduct is thermodynamically preferable,

\footnotetext{
*For correspondence
}

B-P-N-B bonded bis-adduct and N-B bonded adduct could also be realized by varying the mole ratio of boranes. ${ }^{7}$ However, structural evidences were not provided. Recently, we have undertaken a project to address the basicity of amido nitrogen attached to a phosphine group by both experimental work and theoretical calculations. In this regard we have reported various phosphinamnies $\left[\mathrm{Ph}_{2} \mathrm{PNH}\left(\mathrm{CHPh}_{2}\right)\right],\left[\mathrm{Ph}_{2} \mathrm{PNH}\left(\mathrm{CPh}_{3}\right)\right]$ and $\left[\mathrm{Ph}_{2} \mathrm{PNH}\left(\mathrm{CMe}_{3}\right)\right],\left[\mathrm{Ph}_{2} \mathrm{PNH}\left(2,6-\mathrm{Me}_{2} \mathrm{C}_{6} \mathrm{H}_{3}\right)\right]$, and $\left[\mathrm{Ph}_{2}\right.$ $\left.\operatorname{PNH}\left(2,6-{ }^{i} \mathrm{Pr}_{2} \mathrm{C}_{6} \mathrm{H}_{3}\right)\right]$ which were introduced in alkali metal, alkaline earth metal and transition metal chemistry. ${ }^{8,9}$ We have demonstrated from the crystallographic analysis as well as DFT calculation that the P-B bonded mono-adducts are more stable than N-B bonded mono-adducts obtained from various phosphinamines ligands. In continuation with the previous study, we were interested to introduce a pyridyl functional group as a competing basic group with the aminophosphine ligand to compare the basicity of the pyridyl nitrogen, amino nitrogen and the phosphorus atom attached to the amino group towards $\mathrm{BH}_{3}$.

Herein we report the synthetic and structural details of pyridine-2-methylamidophosphine borane bis-adduct $\left[\mathrm{C}_{5} \mathrm{H}_{4} \mathrm{~N}\left(\mathrm{BH}_{3}\right)-\mathrm{CH}_{2} \mathrm{NHP}\left(\mathrm{BH}_{3}\right) \mathrm{Ph}_{2}\right]$ (1a) and pyridine2-methylphosphinoselenoic amide borane adduct $\left[\mathrm{C}_{5} \mathrm{H}_{4}\right.$ $\left.\mathrm{N}\left(\mathrm{BH}_{3}\right)-\mathrm{CH}_{2} \mathrm{NHP}(\mathrm{Se}) \mathrm{Ph}_{2}\right]$ (2a). We also describe the full accounts of DFT study for compounds 1a and 2a to compare the stability of the P-B bonded mono-adducts 
and N-B bonded mono-adducts or bis-adducts considering the energetic and electronic stability of the respective compounds.

\section{Experimental}

\subsection{General Information}

All manipulations of air-sensitive materials were performed with the rigorous exclusion of oxygen and moisture in flame-dried Schlenk-type glassware either on a dual manifold Schlenk line, interfaced to a high vacuum $\left(10^{-4}\right.$ Torr) line, or in an argon-filled M. Braun glove box. Hydrocarbon solvents (toluene and $n$-pentane) were distilled under nitrogen from $\mathrm{LiAlH}_{4}$ and stored in the glove box. ${ }^{1} \mathrm{H}$ NMR $(400 \mathrm{MHz}),{ }^{13} \mathrm{C}\left\{{ }^{1} \mathrm{H}\right\},{ }^{31} \mathrm{P}\left\{{ }^{1} \mathrm{H}\right\}$ NMR (161.9 MHz) and ${ }^{11} \mathrm{~B}\left\{{ }^{1} \mathrm{H}\right\}(128.4 \mathrm{MHz})$ spectra were recorded on a BRUKER AVANCE III-400 spectrometer. BRUKER ALPHA FT-IR spectrometer was used for FT-IR measurement. Elemental analyses were performed on a BRUKER EURO EA at the Indian Institute of Technology Hyderabad. Starting materials $\left[\mathrm{C}_{5} \mathrm{H}_{4} \mathrm{~N}-\mathrm{CH}_{2} \mathrm{NHPPh}_{2}\right](\mathbf{1})$, and $\left[\mathrm{C}_{5} \mathrm{H}_{4} \mathrm{~N}-\mathrm{CH}_{2} \mathrm{NHP}(\mathrm{Se})\right.$ $\mathrm{Ph}_{2}$ ] (2) were prepared according to the literature procedures. ${ }^{8}$

\subsection{Synthesis of $\left[\mathrm{C}_{5} \mathrm{H}_{4} \mathrm{~N}\left(\mathrm{BH}_{3}\right) \mathrm{CH}_{2} \mathrm{NHP}\left(\mathrm{BH}_{3}\right) \mathrm{Ph}_{2}\right](\mathbf{1 a})$}

In a $25 \mathrm{~mL}$ flask, $1(1.0 \mathrm{~g}, 3.41 \mathrm{mmol})$ was dissolved in toluene $(10 \mathrm{~mL})$, borane-dimethyl sulfide $(0.64 \mathrm{~mL}$, $6.82 \mathrm{mmol}$ ) was added drop wise onto this solution. The reaction mixture was then stirred for another $6 \mathrm{~h}$. A white precipitate was formed and filtered off and dried under vacuo. Yield: 1.09 g. (99\%). The title compound was re-crystallized from $\mathrm{CH}_{2} \mathrm{Cl}_{2}$ at $-4^{\circ} \mathrm{C} .{ }^{1} \mathrm{H}$ NMR (400 $\left.\mathrm{MHz}, \mathrm{CDCl}_{3}\right): \delta 8.61\left(\mathrm{~d},{ }^{3} J_{\mathrm{HH}}=8.0 \mathrm{~Hz}, 1 \mathrm{H}, \operatorname{Ar} H\right)$, 7.75-7.64 (m, 4H, $\operatorname{Ar} H), 7.72\left(\mathrm{~d}, 1 \mathrm{H},{ }^{3} J_{\mathrm{HH}}=4.0 \mathrm{~Hz}\right.$, Py-CH), $7.62\left(\mathrm{~d}, 1 \mathrm{H},{ }^{3} J_{\mathrm{HH}}=8.0 \mathrm{~Hz}, \mathrm{Py}-\mathrm{CH}\right), 7.46-7.38$ (m, 6H, $\operatorname{Ar} H$ ), 7.31-7.26 (m, 1H, Py-CH), 4.70-4.65 (dd, $2 \mathrm{H}, J=14.2 \mathrm{~Hz}, 7.6 \mathrm{~Hz}, \mathrm{NH}-\mathrm{CH}_{2-} \mathrm{Py}$ ), 4.25-4.21 $\left(\mathrm{q}, 1 \mathrm{H}, J=14.4 \mathrm{~Hz}, 7.2 \mathrm{~Hz}, \mathrm{NH}-\mathrm{CH}_{2-} \mathrm{Py}\right), 2.60$ (br, 3H, B $H_{3}$ ), 1.17 (br, 3H, B $H_{3}$ ) ppm. ${ }^{13} \mathrm{C}\left\{{ }^{1} \mathrm{H}\right\} \mathrm{NMR}$ $\left(100 \mathrm{MHz}, \mathrm{CDCl}_{3}\right): \delta 156.7(\mathrm{PyC}), 149.2(\mathrm{PyC}), 139.9$ $(\mathrm{Py} C), 139.9$ (P attached $C), 134.3$ (P attached $o-\operatorname{Ar} C$ ), $133.4(\mathrm{P}$ attached $p$-ArC), $128.5(\mathrm{P}$ attached $m$-ArC), 128.4 (P attached $m$-ArC), 127.0 (PyC), $123.84(\mathrm{Py} C)$, 44.5 (Py-C) ppm. ${ }^{31} \mathrm{P}\left\{{ }^{1} \mathrm{H}\right\}$ NMR (161.9 MHz, $\left.\mathrm{CDCl}_{3}\right)$ : $\delta 73.1 \mathrm{ppm} .{ }^{11} \mathrm{~B}\left\{{ }^{1} \mathrm{H}\right\}$ NMR $\left(128.4 \mathrm{MHz}, \mathrm{CDCl}_{3}\right): \delta-$ $14.3 \mathrm{ppm}\left(\mathrm{N}-\mathrm{BH}_{3}\right),-38.4 \mathrm{ppm}\left(\mathrm{P}-\mathrm{BH}_{3}\right)$. FT-IR (selected frequencies): $v=3360(\mathrm{~N}-\mathrm{H}), 2378(\mathrm{~B}-\mathrm{H}), 1432(\mathrm{P}-\mathrm{C})$, $998(\mathrm{P}-\mathrm{N}), 824$ (N-B), $601(\mathrm{P}-\mathrm{B}) \mathrm{cm}^{-1}$.

\subsection{Synthesis of $\left[\mathrm{C}_{5} \mathrm{H}_{4} \mathrm{~N}\left(\mathrm{BH}_{3}\right) \mathrm{CH}_{2} \mathrm{NHP}(\mathrm{Se}) \mathrm{Ph}_{2}\right](2 \mathrm{a})$}

In a $25 \mathrm{~mL}$ flask, $2(1.0 \mathrm{~g}, 2.68 \mathrm{mmol})$ was dissolved in toluene, borane-dimethyl sulfide $(0.25 \mathrm{~mL}, 2.68 \mathrm{mmol})$ was added drop wise on to the solution. The reaction mixture was then stirred for another $6 \mathrm{~h}$. A white precipitate was formed and was filtered through G4 frit and the white residue was dried under vacuo. Yield: $1.03 \mathrm{~g}$ (99\%). The title compound was re-crystallized from $\mathrm{CH}_{2} \mathrm{Cl}_{2}$ at $-4^{\circ} \mathrm{C} .{ }^{1} \mathrm{H}$ NMR $\left(400 \mathrm{MHz}, \mathrm{CDCl}_{3}\right): \delta 8.66$ $\left(\mathrm{d},{ }^{3} J_{\mathrm{HH}}=8.0 \mathrm{~Hz}, 1 \mathrm{H}, \operatorname{Ar} H\right), 7.84-7.74(\mathrm{~m}, 4 \mathrm{H}, \operatorname{Ar} H)$, $7.73\left(\mathrm{~d}, 1 \mathrm{H},{ }^{3} J_{\mathrm{HH}}=4.0 \mathrm{~Hz}, \mathrm{Py}-\mathrm{CH}\right), 7.62(\mathrm{~d}, 1 \mathrm{H}$, $\left.{ }^{3} J_{\mathrm{HH}}=8.0 \mathrm{~Hz}, \mathrm{Py}-\mathrm{CH}\right), 7.46-7.38(\mathrm{~m}, 6 \mathrm{H}, \mathrm{Ar} H), 7.31-$ 7.26 (m, 1H,Py-CH), 4.75-4.70 (dd, 2H, $J=14.2 \mathrm{~Hz}$, $\left.7.6 \mathrm{~Hz}, \mathrm{NH}-\mathrm{CH}_{2} \mathrm{Py}\right), 4.19-4.14$ (q, $1 \mathrm{H}, J=14.4 \mathrm{~Hz}$, $\left.7.2 \mathrm{~Hz}, \mathrm{NH}-\mathrm{CH}_{2-} \mathrm{Py}\right), 2.62$ (br, $\left.3 \mathrm{H}, \mathrm{BH}_{3}\right) \mathrm{ppm} .{ }^{13} \mathrm{C}$ $\left\{{ }^{1} \mathrm{H}\right\}$ NMR $\left(100 \mathrm{MHz}, \mathrm{CDCl}_{3}\right): \delta 156.7(\mathrm{PyC}), 149.2$ (PyC), 139.9 (PyC), 139.9 (P attached $C$ ), 134.3(P attached $o-\operatorname{Ar} C), 133.4(\mathrm{P}$ attached $p-\operatorname{Ar} C), 128.5(\mathrm{P}$ attached $m-\operatorname{Ar} C$ ), $128.4(\mathrm{P}$ attached $m-\operatorname{ArC}$ ), 127.0 $(\mathrm{Py} C), 123.84$ (PyC), 44.5 (Py-C) ppm. ${ }^{31} \mathrm{P}\left\{{ }^{1} \mathrm{H}\right\}$ NMR $\left(161.9 \mathrm{MHz}, \mathrm{CDCl}_{3}\right): \delta 57.6 \mathrm{ppm} .{ }^{11} \mathrm{~B}\left\{{ }^{1} \mathrm{H}\right\}$ NMR $\left(128.4 \mathrm{MHz}, \mathrm{CDCl}_{3}\right): \delta-14.1 \mathrm{ppm}\left(\mathrm{N}-\mathrm{BH}_{3}\right)$. FT-IR (selected frequencies): $v=3270(\mathrm{~N}-\mathrm{H}), 2379(\mathrm{~B}-\mathrm{H}), 1432$ (P-C), $922(\mathrm{P}-\mathrm{N}), 833(\mathrm{~N}-\mathrm{B}), 557(\mathrm{P}=\mathrm{Se}) \mathrm{cm}^{-1}$.

\subsection{Single-Crystal X-Ray Structure Determination and analysis}

Single crystals of compounds $\mathbf{1}$ and $\mathbf{2}$ were obtained from the respective $\mathrm{CH}_{2} \mathrm{Cl}_{2}$ solution under inert atmosphere at a temperature of $-4^{\circ} \mathrm{C}$. In each case, a crystal of suitable dimensions was mounted on a CryoLoop (Hampton Research Corp.) with a layer of light mineral oil and placed in a nitrogen stream at 150(2) K. All measurements were made on an Agilent Supernova Xcalibur Eos CCD detector with graphite-monochromatic $\mathrm{Cu}-\mathrm{K} \alpha(1.54184 \AA)$ radiation. Crystal data and structure refinement parameters are summarized in table 1 . The structures were solved by direct methods (SIR$2004)^{10}$ and refined on $F^{2}$ using the full-matrix leastsquares method; using SHELXL-97. ${ }^{11}$ Non-hydrogen atoms were anisotropically refined. $\mathrm{H}$-atoms were included in the refinement on calculated positions riding on their carrier atoms. The function minimized was $\left.\left.\left[\sum w\left(F o^{2}-F c^{2}\right)^{2}\right](w=1 /] \sigma^{2}\left(F o^{2}\right)+(a P)^{2}+b P\right]\right)$, where $\mathrm{P}=\left(\operatorname{Max}\left(F o^{2}, 0\right)+2 F c^{2}\right) / 3$ with $\sigma^{2}\left(F o^{2}\right)$ from counting statistics. The function $R 1$ and $w R 2$ were $\left(\sum|| F o|-| F c||\right) / \sum|F o|$ and $\left[\sum w\left(F o^{2}-\right.\right.$ $\left.\left.F c^{2}\right)^{2} / \sum\left(w F o^{4}\right)\right]^{1 / 2}$, respectively. The ORTEP-3 program was used to draw the molecule. Crystallographic data (excluding structure factors) for the structures 
Table 1. Crystallographic details of $\left[\mathrm{C}_{5} \mathrm{H}_{4} \mathrm{~N}\left(\mathrm{BH}_{3}\right)-\mathrm{CH}_{2} \mathrm{NHP}\left(\mathrm{BH}_{3}\right) \mathrm{Ph}_{2}\right]$ (1a) and $\left[\mathrm{C}_{5} \mathrm{H}_{4} \mathrm{~N}_{\left(\mathrm{BH}_{3}\right)-}\right.$ $\left.\mathrm{CH}_{2} \mathrm{NHP}(\mathrm{Se}) \mathrm{Ph}_{2}\right](\mathbf{2 a})$.

\begin{tabular}{|c|c|c|}
\hline & $1 \mathbf{a}$ & $2 \mathbf{a}$ \\
\hline CCDC No. & 1418340 & 1418341 \\
\hline Formula & $\mathrm{C}_{18} \mathrm{H}_{23} \mathrm{~B}_{2} \mathrm{~N}_{2} \mathrm{P}$ & $\mathrm{C}_{18} \mathrm{H}_{20} \mathrm{BN}_{2} \mathrm{PSe}$ \\
\hline Formula weight & 319.97 & 385.10 \\
\hline Crystal system & Monoclinic & Monoclinic \\
\hline Space group & $P 2{ }_{1} / \mathrm{c}$ & $P 2_{1} / \mathrm{c}$ \\
\hline $\mathrm{a},[\AA]$ & 13.6661(14) & 13.9339(6) \\
\hline $\mathrm{b},[\AA]$ & $13.7280(17)$ & $13.9605(5)$ \\
\hline c, $[\AA]$ & $9.9298(12)$ & $9.6554(4)$ \\
\hline$\alpha\left[^{\circ}\right]$ & 90 & 90 \\
\hline$\beta,\left[^{\circ}\right]$ & $106.115(12)$ & $106.272(4)$ \\
\hline$\gamma\left[^{\circ}\right]$ & 90 & 90 \\
\hline $\mathrm{V},\left[\AA^{3}\right]$ & 1789.7(4) & $1802.97(13)$ \\
\hline $\mathrm{Z}$ & 4 & 4 \\
\hline Density $\left(\mathrm{mg} / \mathrm{m}^{3}\right)$ & 1.188 & 1.419 \\
\hline $\mathrm{T},[\mathrm{K}]$ & $150(2)$ & $293(2)$ \\
\hline Radiation & $\operatorname{CuK} \alpha(\lambda=1.54184 \AA)$ & $\mathrm{CuK} \alpha(\lambda=1.54184 \AA)$ \\
\hline$\mu, \mathrm{mm}^{-1}$ & 1.328 & 3.638 \\
\hline $\mathrm{F}(000)$ & 680 & 784 \\
\hline Absorption correction & Multi-scan & Multi-scan \\
\hline Reflections collected & 7995 & 7879 \\
\hline Unique reflections & $3374\left[\mathrm{R}_{\mathrm{int}}=0.0275\right]$ & $3284\left[\mathrm{R}_{\mathrm{int}}=0.0468\right]$ \\
\hline Completeness to $\Theta$ & $97.8 \%$ & $94.9 \%$ \\
\hline GOF & 1.046 & 1.013 \\
\hline Refinement method & Full-matrix least-squares on $\mathrm{F}^{2}$ & Full-matrix least-squares on $\mathrm{F}^{2}$ \\
\hline $\mathrm{R}_{1} ; \mathrm{wR}_{2}$ & $0.0430 ; 0.1236$ & $0.0470 ; 0.1180$ \\
\hline
\end{tabular}

reported in this article have been deposited with the Cambridge Crystallographic Data Centre as supplementary publication nos. CCDC 1418340 (1a) and 1418341 (2a). Copies of the data can be obtained free of charge on application to CCDC, 12 Union Road, Cambridge CB21EZ, UK (fax: + (44)1223-336-033; email: deposit@ccdc.cam.ac.uk).

\section{Results and Discussion}

The bis-borane adduct of pyridine-2-methylaminophosphine $\left[\mathrm{C}_{5} \mathrm{H}_{4} \mathrm{~N}\left(\mathrm{BH}_{3}\right)-\mathrm{CH}_{2} \mathrm{NHP}\left(\mathrm{BH}_{3}\right) \mathrm{Ph}_{2}\right]$ (1a) was prepared in good yield by Lewis acid base reaction between the pyridine-2-methylaminophosphine (1) and $\mathrm{BH}_{3} \cdot \mathrm{SMe}_{2}$ in 1:1 molar ratio in toluene at room temperature followed by recrystallization from dichloromethane solution (scheme 1). In an analogous reaction, the mono-borane adduct of pyridine-2-methylphosphinoselenoic amide $\left[\mathrm{C}_{5} \mathrm{H}_{4} \mathrm{~N}\left(\mathrm{BH}_{3}\right)-\mathrm{CH}_{2} \mathrm{NHP}(\mathrm{Se}) \mathrm{Ph}_{2}\right]$ (2a) was isolated by the reaction with pyridine-2-methylphosphinoselenoic amide (2) and $\mathrm{H}_{3} \mathrm{~B} \cdot \mathrm{SMe}_{2}$ in 1:1 molar ratio (scheme 1). Attempts to isolate mono-borane adduct of 1 either $\left[\mathrm{C}_{5} \mathrm{H}_{4} \mathrm{~N}\left(\mathrm{BH}_{3}\right)-\mathrm{CH}_{2} \mathrm{NHPPh}_{2}\right]$ or $\left[\mathrm{C}_{5}\right.$ $\left.\mathrm{H}_{4} \mathrm{NCH}_{2} \mathrm{NHP}\left(\mathrm{BH}_{3}\right) \mathrm{Ph}_{2}\right]$ did not meet success as always compound 1a was isolated as stable product. Both the compounds 1a and 2a were characterized by spectroscopic/analytical techniques and the solid state structures of the compounds were established by single crystal X-ray diffraction analysis.

The formation of the bis-borane adduct 1a from pyridine-2-methylaminophosphine and mono-borane adduct 2a from pyridine-2-methylphosphinoselenoic amide can easily be followed by ${ }^{1} \mathrm{H}$ NMR spectroscopy, since additional resonances are observed for the borane $\left(\mathrm{BH}_{3}\right)$ groups attached to the pyridyl nitrogen and phosphorus atoms (for 1a) and pyridyl nitrogen atom for

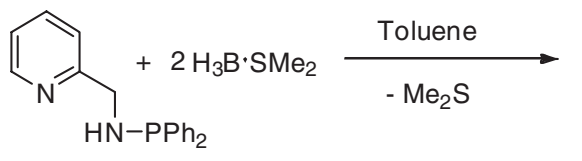

(1)

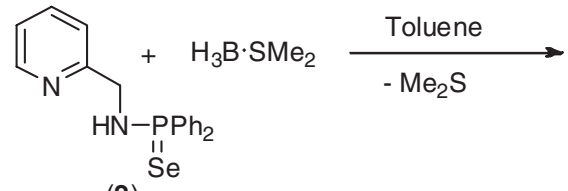

(2)

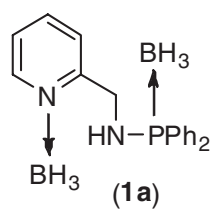

(1a)

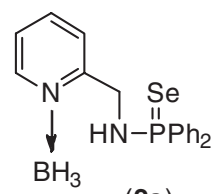

(2a)
Scheme 1. Synthesis of borane-adducts 1a and 2a from compounds $\mathbf{1}$ and $\mathbf{2}$, respectively. 
2a as broad signals centered at $\delta 2.63$ and 1.17 (1a), 2.62 (2a) ppm, respectively. The two methylene protons present in compounds $\mathbf{1}$ and $\mathbf{2}$, resonate as doublet of a doublet centered at $\delta 4.67$ ( for 1a) and 4.72 (for 2a) due to coupling of two diastereotopic protons with adjacent $\mathrm{N}-\mathrm{H}$ proton. As a result, two sets of coupling constants were observed for both the compounds $(14.2$ and $7.6 \mathrm{~Hz}$ ). The pyridyl protons in compound 1a display the resonances as two doublets centered at $\delta 7.73$ and $7.62 \mathrm{ppm}(\delta 7.72$ and $7.61 \mathrm{ppm}$ for $\mathbf{2 a})$ and two multiplets at $\delta 7.46-7.38$ and $7.31-7.26 \mathrm{ppm}$ ( $\delta$ 7.45-7.37 and 7.31-7.25 ppm for 2a). In ${ }^{13} \mathrm{C}\left\{{ }^{1} \mathrm{H}\right\}$ NMR spectra of $\mathbf{1 a}$ and $\mathbf{2 a}$, the resonances of pyridyl ring carbons were observed at higher chemical shift values ( $\delta 156.7,149.2$ and 139.9 for $1 \mathbf{a}$ and $\delta$ 156.5, 149.2 and 139.8 for $\mathbf{2 a}$ ) which are in agreement with the values reported in the literature. ${ }^{12}$ The ${ }^{31} \mathrm{P}\left\{{ }^{1} \mathrm{H}\right\}$ of both the compounds show a sharp singlet at $\delta 73.1$ and $57.6 \mathrm{ppm}$ consistent with the presence of one phosphorus atom in each compound. However, the bis-borane compound is very sensitive towards oxygen and underwent oxidation to show an additional signal at $\delta 24.1$ ppm which can be assigned to the $\mathrm{P}=\mathrm{O}$ group (see Supporting Information). The ${ }^{11} \mathrm{~B}\left\{{ }^{1} \mathrm{H}\right\}$ NMR spectra also confirmed the formation of bis-borane adduct for $\mathbf{1 a}$ [ $\delta$-14.3 ppm, $\left(\mathrm{PyN}_{-} \mathrm{BH}_{3}\right)$, and -38.4 ppm, $\left.\left(\mathrm{P}_{-}-\mathrm{BH}_{3}\right)\right]$ and mono-borane adduct for $\mathbf{2 a}\left(-14.1 \mathrm{ppm}, \mathrm{PyN}_{-} \mathrm{BH}_{3}\right)$. The ${ }^{31} \mathrm{P}\left\{{ }^{1} \mathrm{H}\right\}$ and ${ }^{11} \mathrm{~B}\left\{{ }^{1} \mathrm{H}\right\}$ NMR data are very similar to our previously reported aminophosphine borane complexes of the type $\left[\mathrm{Ph}_{2} \mathrm{P}\left(\mathrm{BH}_{3}\right) \mathrm{NHR}\right]\left(\mathrm{R}=\mathrm{tBu}, \mathrm{Ph}_{2} \mathrm{CH}\right.$, $\left.\mathrm{Ph}_{3} \mathrm{C}, 2,6-\mathrm{Me}_{2} \mathrm{C}_{6} \mathrm{H}_{3}\right) .{ }^{8}$ In FT-IR spectra characteristic band for P-B bond stretching at $601 \mathrm{~cm}^{-1}$ was observed for $1 \mathrm{a}$ along with another absorption band at $2378 \mathrm{~cm}^{-1}$ assigned for B-H stretching frequency. For compound 2a, the absorption band at $557 \mathrm{~cm}^{-1}$ can be assigned to $\mathrm{P}=$ Se bond along with a band at $2379 \mathrm{~cm}^{-1}$ assigned to $\mathrm{B}-\mathrm{H}$ stretching frequency. These values are in agreement with the values reported in the literature. ${ }^{13}$ To study in the solid state, the structures of the compounds 1a and 2a were established by single crystal X-ray diffraction analysis.

Both the bis-borane adduct 1a and the mono-borane adduct 2a crystallize in the monoclinic space group $P 2_{1} / \mathrm{c}$ having four independent molecules in the respective unit cell. The details of the structural parameters for compounds $\mathbf{1 a}$ and $\mathbf{2 a}$ are given in table 1 . The molecular structures of $\mathbf{1 a}$ and $\mathbf{2 a}$ are shown in figures 1 and 2 , respectively. The $\mathrm{P}-\mathrm{B}$ bond distance of [1.909(2)] $\AA$ in 1a is within the range of our previously reported values for amidophosphine borane compounds $\left[\mathrm{Ph}_{2} \mathrm{P}\left(\mathrm{BH}_{3}\right) \mathrm{NH}\left(\mathrm{CR}_{3}\right)\right](\mathrm{R}=\mathrm{Me}, \mathrm{Ph}$, etc. $)$ range. ${ }^{9}$ The B-N distances [1.597(2) $\AA$ for 1a and 1.593(6) $\AA$ for $\mathbf{2 a}$ ] are also in the acceptable range to consider them

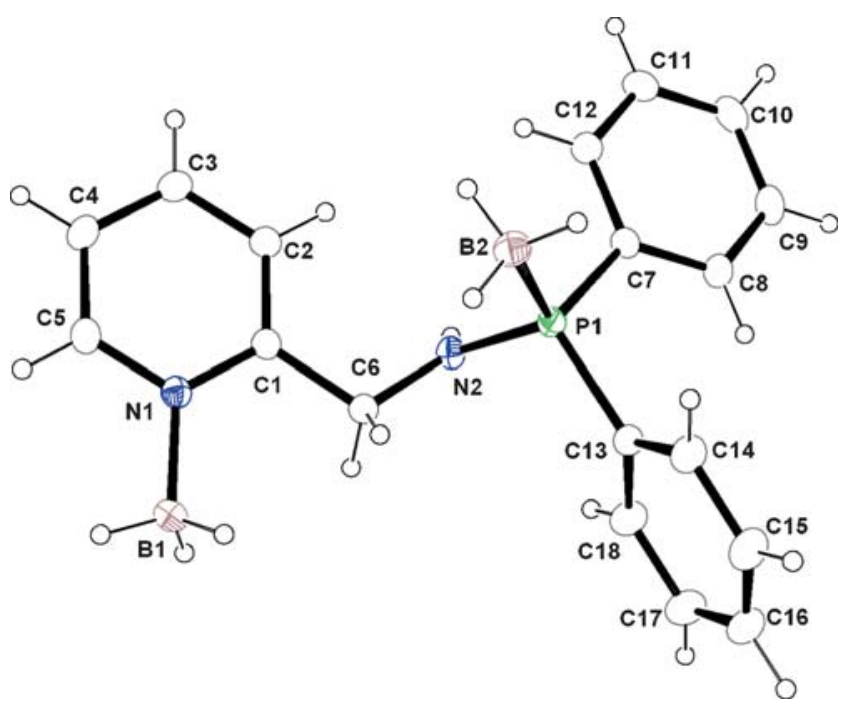

Figure 1. ORTEP diagram of 1a with thermal displacement parameters drawn at the $30 \%$ probability level. Selected bond lengths $[\AA]$ and bond angles $\left[{ }^{\circ}\right]$ : P1-N2 1.6669(13), P1-B2 1.9087(19), P1-C7 1.8099(16), P1-C13 1.8129(16), N1-C1 1.359(2), C1-C6 1.512(2), C6-N2 1.463(2), N1B1 1.597(2), B2-P1-N2 112.08(8), B2-P1-C7 112.39(8), B2-P1-C13 112.54(9), P1-N2-C6 119.80(11), N1-C1-C6 117.10(14), B1-N1-C1 122.38(13), B1-N1-C5 118.37(14), N2-P1-C13 108.68(7), N2-P1-C7 103.64(7).

as coordinate bond. The $\mathrm{P}-\mathrm{N}$ distances $[1.6669(13) \AA$ for 1a and 1.657(3) $\AA$ for 2a] are similar and indicate the presence of covalent bond between nitrogen and phosphorus atoms in both the compounds. Thus, in both the cases, the amino nitrogen is not basic enough to form a adduct with borane $\left(\mathrm{BH}_{3}\right)$ even if excess amount of borane is used. The solid state structures of all the aminophosphine-borane adducts are consistent with the dynamic nature of the molecules observed in multinuclear NMR spectra (vide supra).

Thus, we have observed that the basicities of pyridyl nitrogen and the phosphorus atoms in the aminophosphine moiety of compound $\mathbf{1}$ are almost similar and several attempts to isolate the mono-borane adduct of 1 either as $\left[\mathrm{C}_{5} \mathrm{H}_{4} \mathrm{~N}\left(\mathrm{BH}_{3}\right)-\mathrm{CH}_{2} \mathrm{NHPPh}_{2}\right]$ or $\left[\mathrm{C}_{5} \mathrm{H}_{4} \mathrm{NCH}_{2} \mathrm{NHP}\left(\mathrm{BH}_{3}\right) \mathrm{Ph}_{2}\right]$ did not meet with success. In compound 2 , the phosphorus atom is blocked by a selenium functionality through the formation of $\mathrm{P}=\mathrm{Se}$ bond and can not act as Lewis base as the $\mathrm{P}$ atom is now +5 oxidation state. Thus, the amino nitrogen $(\mathrm{NH})$ and the pyridyl nitrogen atoms are now available for adduct formation with borane $\left(\mathrm{BH}_{3}\right)$. However, it is observed that only pyridyl nitogen can form the adduct with $\mathrm{BH}_{3}$ and the amino nitrogen $(\mathrm{NH})$ remains inert even in the presence of excess amount of borane. Because of these observations, we were interested to calculate theoretically the limiting conditions for adduct formation 


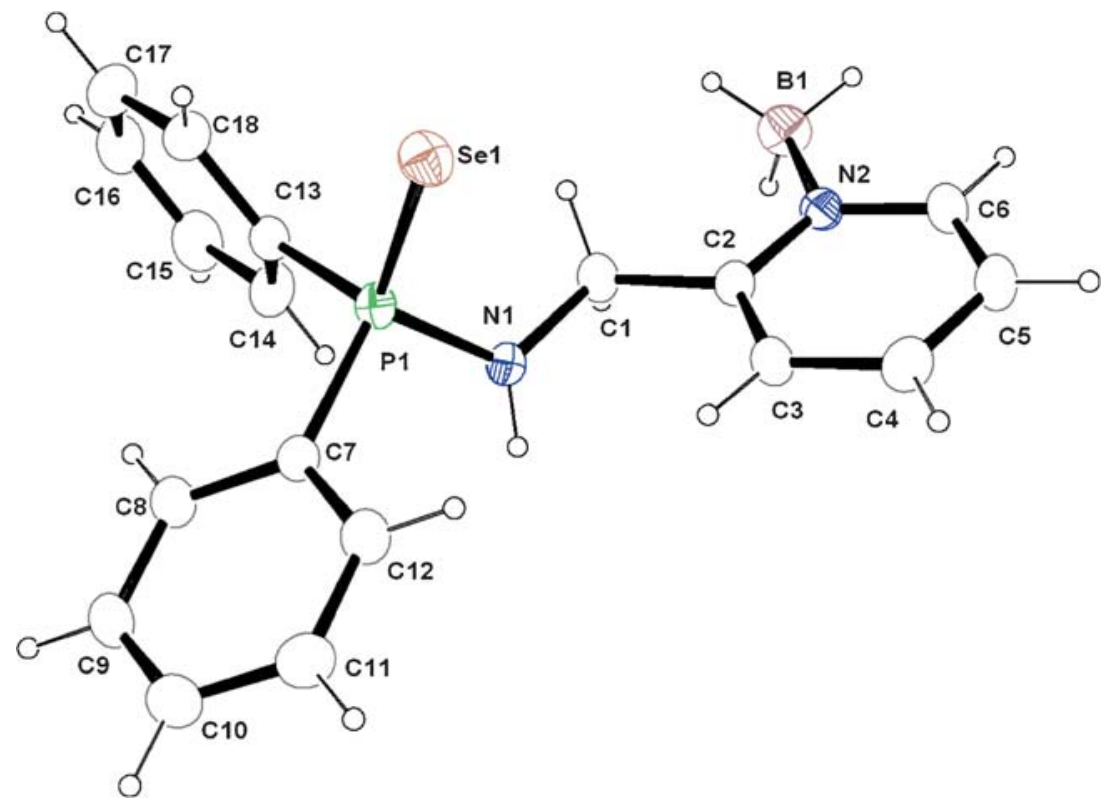

Figure 2. ORTEP diagram of 2a with thermal displacement parameters drawn at the $30 \%$ probability level. Selected bond lengths $[\AA]$ and bond angles $\left[^{\circ}\right]$ : P1-N1 1.657(3), P1-Se1 2.1067(12), P1-C7 1.804(4), P1-C13 1.809(4), N1-C1 1.461(4), C1-C2 1.513(5), N2-B1 1.593(6), B1-N21-C2 123.2(4), B1-N2-C6 118.6(4), Se1-P1-N1 113.01(12), Se1-P1-C7 113.10 (14), Se1-P1-C13 111.94(15), N1-P1-C7 102.49(18), N1-P1-C13 107.72 (19), C7-P1-C13 107.99(19).

by pyridyl nitrogen, phosphorus atoms and the amino nitrogen using their frontier orbitals HOMO and LUMO.

\subsection{DFT Calculations}

3.1a General: Compound 1a was obtained via the reaction of an equimolar ratio of the pyridine-2-methylaminophosphine ligand (1) and borane $\left[\mathrm{BH}_{3} \cdot \mathrm{SMe}_{2}\right]$. The compound 1 contains three possible binding sites for the formation of borane adduct: (a) pyridyl nitrogen, (b) phosphorous, and (c) amino nitrogen. The first principle calculations were performed on the gas phase addition of borane $\left(\mathrm{BH}_{3}\right)$ to various pyridine-2-methylaminophosphine ligands. The main focus of our study was to explore the preferential Lewis basicity of pyridyl nitrogen, amino nitrogen or phosphorous atoms (depending on the ligand) upon reaction with borane
$\left(\mathrm{BH}_{3}\right)$. We have chosen several model ligand systems (figure 3 a-e) for this purpose along with experimentally synthesized compounds (1a and $\mathbf{2 a}$ ). All the model structures were drawn in Gauss View ${ }^{14}$ and optimized at $\mathrm{HF} / 3-21 \mathrm{G}(\mathrm{d})$ level. Higher level single point energy calculations were done at B3LYP/6-311+G(2d,p) ${ }^{15}$ level of electronic structure calculation using Gaussian 09(Rev B.01) software. ${ }^{16}$ We have computed the structure and energetics of each of the free ligands listed in figure 3, the free $\mathrm{BH}_{3}$ molecule, and each pyridine-2methylaminophosphine-borane compounds by following the geometry optimization procedure. The optimized structures were confirmed to be (local) minima by the absence of imaginary vibrational frequencies. Theoretical analysis of all the systems for the adduct formation with borane $\left(\mathrm{BH}_{3}\right)$ was presented considering the stabilization energy of each adduct and subsequently, further investigations have been carried out in

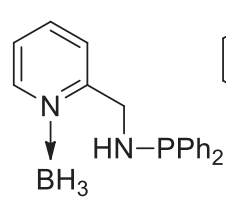

(a)

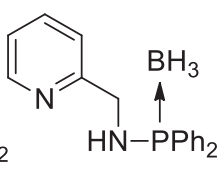

(b)

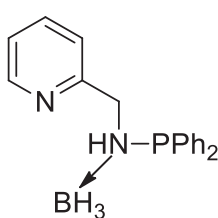

(c)

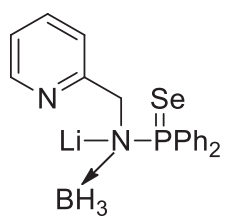

(d)

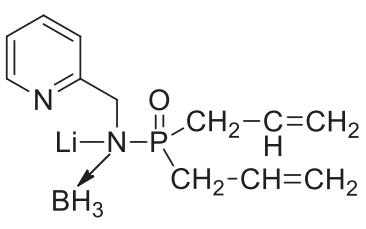

(e)

Figure 3. Selected pyridine-2-methylaminophosphine ligands and its chalcogen derivatives used for DFT calculations. 


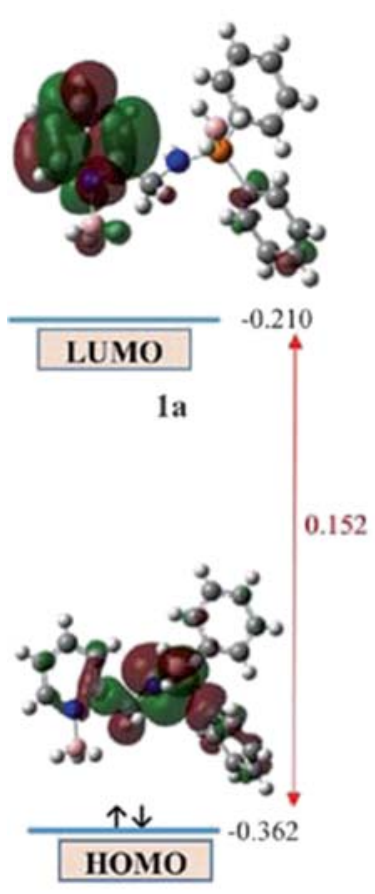

(a)

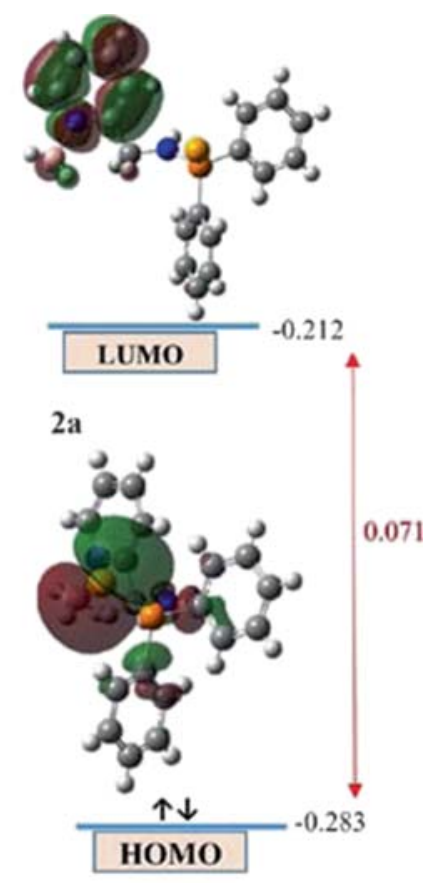

(b)
Figure 4. Frontier KS-molecular orbitals for bis-adduct of 1a and mono-adduct of $\mathbf{2 a}$.

the quest for the reaction center of $\mathrm{BH}_{3}$ at the less basic amino nitrogen site. After a random search considering various electronic and steric factors through different functional groups (results are not shown), the ligands $\mathbf{3 d}$ and $\mathbf{3 e}$ were found to be appropriate for formation of mono-adducts involving amino nitrogen. We have also performed frontier KS-molecular orbital calculations to investigate the electronic stability of adducts. 3.1b DFT analysis: The reaction of $\mathrm{BH}_{3}$ with ligand (1) for the formation of bis-adduct (1a) is exothermic with stabilization energy of $-64.7 \mathrm{~kJ} / \mathrm{mol}$. The phosphorus, pyridyl and amine nitrogen atoms bonded mono-adducts are stabilized by $-33.2,-30.6$ and -22.5 $\mathrm{kJ} / \mathrm{mol}$, respectively. The values indicate the least basicity for the amine nitrogen bonded adduct; other two reaction sites have significant values of binding energies for mono-adducts. Our predicted stability for bisadduct complements the experimental results regarding the possible formation of 1a over the other theoretically obtained mono-adducts. The mono-borane adduct (2a) having blocked at P-site, has two possible sites for reaction with $\mathrm{BH}_{3}$; pyridyl and amine nitrogen atoms. However, the adduct formed through former type nitrogen is stable by $-28.5 \mathrm{~kJ} / \mathrm{mol}$ as compared to the latter. After studying many functional groups in the quest of amine nitrogen bonded adducts, we have found that mono lithiated compounds (P blocked) having phenyl and vinyl functional groups attached to the phosphorus atom can serve the purpose of stabilizing amino nitrogen bonded mono borane-adducts. The suitable choices of p-substituted functional groups helped us to tune the basicity of two nitrogen sites. The complexes $\mathbf{3 d}$ and 3e have stabilization energies of values -30.7 and -43.5 $\mathrm{kJ} / \mathrm{mol}$, respectively. The adducts formed by the reactions of $\mathrm{BH}_{3}$ to the pyridyl nitrogen centers of ligands, 3d and 3e, have stabilization energies of values -27.9 and $-39.0 \mathrm{~kJ} / \mathrm{mol}$, respectively.

We also calculated the HOMO-LUMO energy gap for adducts, and the orbital pictures are shown in figures 4 and 5. The molecular orbital analysis is also

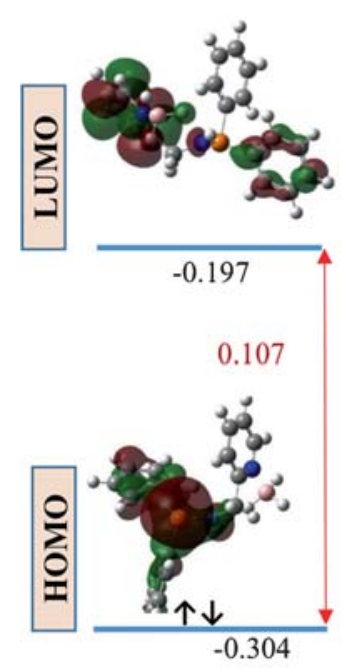

(a)

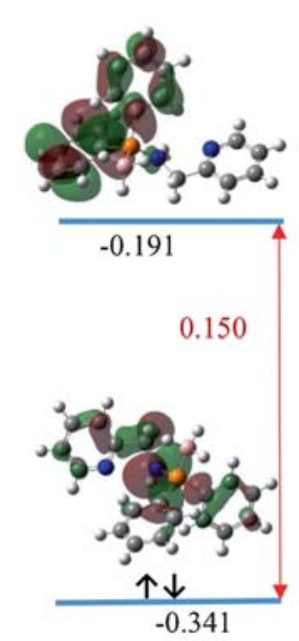

(b)

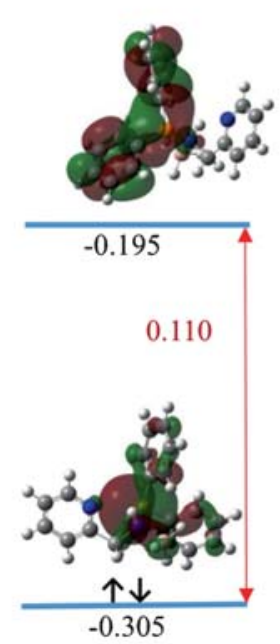

(c)

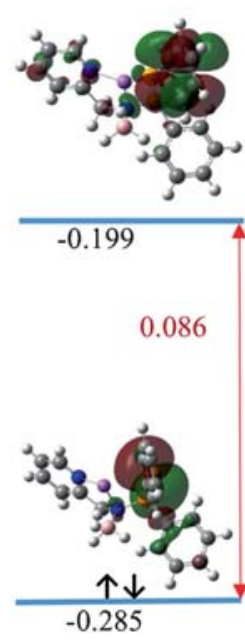

(d)

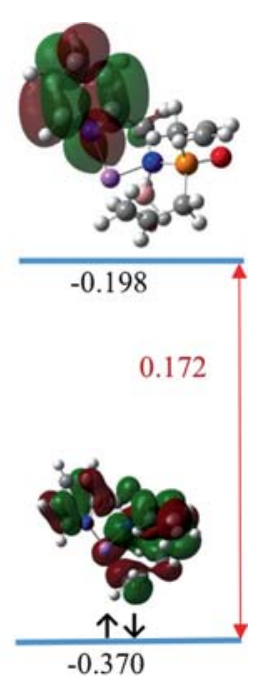

(e)

Figure 5. Frontier KS-molecular orbitals for mono-borane adduct of $\mathbf{1}$ (a, b and c), lithium (divinylphosphinooxide-2-pyridinylmethyl) ligand (d) and lithium (diphenylphosphinoselenoyl-2-pyridinylmethyl)) (e). 
well-consistent with the energetic investigations. From the HOMO-LUMO calculations, it is evident that the bis-adduct is more favorable compared to other monoborane adducts; the energy gap $(0.152 \mathrm{eV})$ of bis-adduct $\mathbf{1 a}$ is higher than other mono borane adducts $(\mathbf{3 a}, \mathbf{3 b}$ and 3c). As a consequence, we could isolate only bis-adduct of pyridine-2-methylaminophosphine experimentally.

When we used penta-valent phosphorus atom by blocking with selenium atom in compound $\mathbf{2}$ (scheme 1), we observed that only pyridyl nitrogen showed tendency for adduct formaton, and amino nitrogen (-NH) remained unactivated even in the presence of excess amount of borane. A further interesting observation is that blocking at phosphorus atom with Se atom results in the destabilization of the product $2 \mathrm{a}(0.071 \mathrm{eV})$ with respect to the bis-borane adduct, $\mathbf{1 a}(0.152 \mathrm{eV})$. In the phosphorus $(\mathrm{V})$ atom, due to $\mathrm{N}(\mathrm{p} \pi) \rightarrow \mathrm{P}(\mathrm{d} \pi)$ back bonding, the electron density of the amino nitrogen is reduced to some extent in comparison with pyridyl nitrogen which remains free. The lone pair of electrons resides outside of the plane of the ring and does not participate in aromatic delocalization. So in case of compound $\mathbf{2 a}$, favorable adduct formation is at the pyridyl $\mathrm{N}$ site. One of our goals was to activate the less basic amino nitrogen site. From our computational study, we observed that the accumulation of free negative charge at amino nitrogen center via the formation of lithiated diphenylphosphinoselenoyl-2-pyridinylmethyl (3d) and lithiated divinylphosphinooxide-2-pyridinylmethyl (3e) compounds are able to make $\sigma$-donation to the electron deficient borane. The electron cloud is more localized at amino nitrogen to behave as Lewis base. The latter ligand, having HOMO-LUMO gap of $0.172 \mathrm{eV}$ has higher potential to bind with $\mathrm{BH}_{3}$ through amino nitrogen atom. Computationally, we also have found out a way to activate the less basic amino nitrogen site and as it can be seen that this mono-borane adduct is more stabilized by nearly $-0.022 \mathrm{eV}$ than the corresponding bis-adduct 1a. This mono-borane amine adduct can be useful as a polymer stabilizer if it is experimentally realized.

\section{Conclusions}

In summary, we have presented the synthesis and structural characterization of pyridine-2-methylaminophosphine-borane adducts, $\mathbf{1 a}$ and $\mathbf{2} \mathbf{a}$; formation of the bis-borane adduct (1a) indicates similar basicity of the pyridyl nitrogen and the phosphorus atoms in pyridine2-methylaminophosphine. However, the mono-borane adduct $\mathbf{2 a}$ is formed through coordination of pyridyl nitrogen when phosphorus atom is blocked by selenium atom via the formation of $\mathrm{P}=\mathrm{Se}$. In addition, we have also demonstrated that the P-coordinated borane is more stable to form $\mathrm{N}$-coordinated borane by DFT calculations. However, the $\mathrm{N}$-coordinated borane adduct resulting from the pyridine nitrogen can be stabilized if the phosphorus atom is blocked with chalcogenides. We have also theoretically observed that less basic amino nitrogen site can also have enhanced basicity through the formation of lithium complex of the corresponding ligands.

\section{Supplementary Information}

The NMR spectra of compounds 1a and 2a and all the theoretical calculation details are given in supplementary information which is available at www.ias.ac.in/ chemsci.

\section{Acknowledgements}

This work is supported by the Ministry of New and Renewable Energy (MNRE), India under project no. $103 / 209 / 2013-N T$, dated, 29 ${ }^{\text {th }}$ September, 2014. The instrumental facilities were provided by the Indian Institute of Technology Hyderabad (IITH) and part of the simulations was performed in HPC facility, Indian Institute of Technology Hyderabad, India. HA thanks UGC, India for his PhD fellowship.

\section{References}

1. Britovsek G J P, Gibson V C and Wass D F 1999 Angew. Chem. Int. Ed. $\mathbf{3 8} 428$

2. Kempe R 2000 Angew. Chem. Int. Ed. 39468

3. (a) Cowley A H, Dewar M J S, Jackson W R and Jennings W B 1970 J. Am. Chem. Soc. 92 5206; (b) Verkade J G 1972/73 Coord. Chem. Rev. 9 1; (c) Dakternicks D and Di Giacomo R 1985 Phosphorus Sulfur 24 217; (d) Schiff D E, Richerson Jr J W, Jecoson R A, Cowley A H and Lasch J 1984 Inorg. Chem. 23 3373; (e) Gonbeau D, Sanchez M and Guillouzo G P 1981 Inorg. Chem. 201966

4. Grec D, Hubert-Pfalzgraf L G, Grand A and Riess J G 1980 J. Am. Chem. Soc. 1027134

5. (a) Jouany C, Laurent J P and Jugie G 1974 J. Chem. Soc. Dalton Trans. 1510; (b) Noeth H and Vetter H J 1963 Chem. Ber 96 1298; (c) Burg A B and Slota Jr P J 1960 J. Am. Chem. Soc. 822145

6. (a) Febvay J, Casablanka F and Riess J G 1985 Inorg. Chem. 24 3235; (b) Grec D, Hubert-Pfalzgraf L G, Grand A and Riess J G 1985 Inorg. Chem. 24 4642; (c) Kanjolia R K, Krannic L K and Watkins C L 1985 Inorg. Chem. 24 445; (d) Kanjolia R K, Krannic L K and Watkins C L 1986 J. Chem. Soc. Dalton Trans. 2345; (e) Neilson P W, Neilson R H 1980 Inorg. Chem. 19 1875; (f) Morton D W and Neilson R H 1982 Organometallics 1 289; (g) Morton D W and Neilson R H 1982 Organometallics 1623 
7. (a) Kanjolia R K, Krannic L K and Watkins C L 1987 Inorg. Chem. 26 222; (b) Kanjolia R K, Srivastava D K, Watkins C L and Krannic L K 1989 Inorg. Chem.28 3341 and the references therein

8. Kottalanka R K, Laskar P, Naktode K, Mallik B S and Panda T K 2013 J. Mol. Struct. 1047302

9. (a) Kottalanka R K, Naktode K and Panda T K 2013 J. Mol. Struct. 1036 188; (b) Naktode K, Kottalanka R K and Panda R K 2012 New J. Chemistry 36 2280; (c) Kottalanka R K, Naktode K, Anga S, Nayek H P and Panda T K 2013 Dalton Trans. 42 4947; (d) Kottalanka R K, Anga S, Naktode K, Laskar P, Nayek H P and Panda T K 2013 Organometallics 32 4473; (e) Kottalanka R K, Harinath A, Bhattacharjee J, Babu H V, and Panda T K 2014 Dalton Trans. 43 8757; (f) Bhattacharjee J, Kottalanka R K, Harinath A and Panda T K 2014 J. Chem. Sci. 126 1463; (g) Naktode K, Bhattacharjee J, Chakrabarti A and Panda T K $2015 \mathrm{~J}$. Chem. Sci. 127 265; (h) Kottalanka R K, Harinath A and Panda T K 20152015 RSC Adv. 537755

10. Altomare A, Burla M C, Camalli G, Cascarano G, Giacovazzo C, Gualiardi A and Polidori G 1994 J. Appl. Cryst. 27435

11. Sheldrick G M 2008 Acta Cryst. A64 112

12. Mei L, Ming T H, Rong L Q, Jie S, Zhong Y S and Liang L X 2009 J. Chem. Sci. 121435
13. Odom J D, Hudgens B A and Durig J R 1973 J. Phys. Chem. 771972

14. Roy Dennington, Todd Keith and John Millam 2009 GaussView, Version 5 (Shawnee Mission KS: Semichem Inc.)

15. (a) Becke D 1993 J. Chem. Phys. 98 5648; (b) Lee C, Yan W and Parr R G 1988 Phys. Rev. B 37785

16. M J Frisch, G W Trucks, H B Schlegel, G E Scuseria, M A Robb, J R Cheeseman, G Scalmani, V Barone, B Mennucci, G A Petersson, H Nakatsuji, M Caricato, X Li, H P Hratchian, A F Izmaylov, J Bloino, G Zheng, J L Sonnenberg, M Hada, M Ehara, K Toyota, R Fukuda, J Hasegawa, M Ishida, T Nakajima, Y Honda, O Kitao, H Nakai, T Vreven, J A Montgomery, Jr., J E Peralta, F Ogliaro, M Bearpark, J J Heyd, E Brothers, K N Kudin, V N Staroverov, T Keith, R Kobayashi, J Normand, K Raghavachari, A Rendell, J C Burant, S S Iyengar, J Tomasi, M Cossi, N Rega, J M Millam, M Klene, J E Knox, J B Cross, V Bakken, C Adamo, J Jaramillo, R Gomperts, R E Stratmann, O Yazyev, A J Austin, R Cammi, C Pomelli, J W Ochterski, R L Martin, K Morokuma, V G Zakrzewski, G A Voth, P Salvador, J J Dannenberg, S Dapprich, A D Daniels, O Farkas, J B Foresman, J V Ortiz, J Cioslowski and D J Fox 2010 Gaussian 09, Revision B.01 (Wallingford CT: Gaussian, Inc.) 